\title{
Chironomids can be reliable proxies for Holocene temperatures. A comment on Velle et al. (20 I0)
}

(C) The Author(s) 2012

Reprints and permission:

sagepub.co.uk/journalsPermissions.nav DOI: 10.1 I 77/09596836/2449757

hol.sagepub.com

(SAGE

\author{
Stephen J Brooks,' Yarrow Axford, ${ }^{2}$ Oliver Heiri, ${ }^{3}$ Peter G \\ Langdon ${ }^{4}$ and Isabelle Larocque-Tobler ${ }^{5}$
}

\begin{abstract}
Velle et al. (The Holocene 20 (2010) 989-1002) discussed discrepancies between Scandinavian Holocene chironomid-inferred temperature estimates, which they attribute to the response of chironomids to environmental variables other than temperature and to taxonomic shortcomings. They suggest ways in which the reliability of chironomid-based paleotemperature reconstructions could be improved by taking into account ecological complexity. While we agree with many of their recommendations, based on the results of other work, we think their paper is unnecessarily pessimistic regarding the ability of existing chironomid-based temperature inference models to provide reliable estimates of past temperature. We offer a critique of the main points discussed by Velle et al. (2010) and provide evidence that chironomid-based temperature inference models can reliably reconstruct mean July air temperature in the Lateglacial and Holocene over millennial and centennial timescales.
\end{abstract}

\author{
Keywords \\ chironomids, Holocene, lake depth, lake trophic state, $\mathrm{pH}$, temperature inference
}

Received 8 July 20I I; revised manuscript accepted I 5 November 20 I I

\section{Introduction}

The paper of Velle et al. (2010) has re-opened the 20 year old debate (Hann et al., 1992; Walker and Mathewes, 1989; Warwick, 1989) concerning whether chironomid assemblages are reliable quantitative indicators of past summer temperatures. Velle et al. (2010) acknowledge that chironomid-based temperature records can provide reliable reconstructions of climatic variability during the Lateglacial period. They focus their discussion on temperature reconstruction during the climatologically more stable Holocene and discuss a subset of Holocene temperature reconstructions from Scandinavia, pointing out differences between these reconstructions and arguing that parameters other than temperature may be responsible for these differences. They suggest that similar issues may detract from the reliability of chironomid-based Holocene temperature reconstructions in other regions.

We agree that, like all climate reconstruction methods based on proxies, chironomid-based temperature reconstructions can be influenced by confounding factors (Brooks, 2006; Heiri and Lotter, 2003, 2005). This has long been recognized and Velle et al. (2010) provide a useful review of some of the problems. However, we wish to clarify that there is no doubt that chironomids can provide reliable estimates of past temperatures, including robust estimates of the associated prediction error which incorporate the response to other variables. This is demonstrated by the many chironomid records that have provided accurate temperature reconstructions for the Lateglacial and Holocene, as evaluated by comparison with independent climate proxies (e.g. Brooks and Birks, 2000; Clegg et al., 2010; Heiri et al., 2007; Levesque et al., 1993), and that have reflected the small-scale fluctuations apparent in meteorological records over the last 100+ years (Langdon et al., 2011; Larocque and Hall, 2003;
Larocque et al., 2009). Chironomids offer several advantages over other quantitative temperature proxies (Brooks, 2003) and the requirement for multiproxy and multisite studies to separate signal from noise is equally true for other climate proxies, including lacustrine proxies and proxies from other archives such as tree rings, peats, speleothems and ice cores.

Like any proxy method, chironomid-based temperature reconstructions should not be applied uncritically. Analogue statistics are routinely calculated to detect non-analogue situations (e.g. Axford et al. 2011; Heiri et al., 2007; Larocque-Tobler et al., 2010a), although WA-PLS methods work well in non-analogue situations (Birks et al., 2010). Telford and Birks (2011) have provided a method to test the statistical significance of a temperature reconstruction against random data, but the results of this test must be considered alongside other palaeoecological and environmental evidence because failure of the test does not necessarily mean a reconstruction is unusable, rather that it should be treated more cautiously. The challenge for palaeoecologists is to identify further

\footnotetext{
'Natural History Museum, UK

${ }^{2}$ Northwestern University, USA

${ }^{3}$ Institute of Plant Sciences and Oeschger Centre for Climate Change

Research, Switzerland

${ }^{4}$ University of Southampton, UK

${ }^{5}$ OCCR and Institute of Geography, University of Bern, Switzerland
}

\section{Corresponding author:}

Stephen J Brooks, Department of Entomology, Cromwell Road, London SW7 5BD, UK.

Email:s.brooks@nhm.ac.uk 
strategies that can detect non-temperature artefacts in chironomidbased temperature records and to constrain a priori the types of environments in which chironomids perform well in tracking past temperature changes. Velle et al. (2010) provide a valuable set of recommendations for successful chironomid analysis which we largely endorse. However, the paper also makes several assertions that are not generally supported by the breadth of chironomid studies conducted over the past two decades. Here we seek to advance the discussion by providing another perspective on the utility of chironomids for reconstructing palaeotemperatures and evaluating some of the possible complications discussed by Velle et al. (2010).

\section{Temperature as a driver of chironomid distribution and abundance}

Calibration data sets based on samples of modern chironomids across long temperature gradients show a strong relationship between chironomid assemblage composition and summer air temperature (e.g. Brooks and Birks, 2001; Larocque et al., 2001; Lotter et al., 1997; Olander et al., 1999). For this reason chironomid-based temperature inference models can be developed with excellent performance statistics. However, Velle et al. (2010) imply that the main reason for the high performance of these models is because the temperature gradient is maximised in the calibration data set and the gradients of other environmental variables are minimised, rather than temperature being a particularly significant variable in driving the composition of chironomid assemblages. The reader may gain the impression that chironomids could be used to infer any variable provided the gradient length of the parameter is as long as possible and the influence of other variables is reduced. However, this overlooks the fact that the performance statistics of chironomid-based temperature inference models far exceed the performance statistics of other chironomid-based models designed to infer other variables such as total phosphorus (Brooks et al., 2001; Langdon et al., 2006), total nitrogen (Brodersen and Anderson, 2002), dissolved oxygen (Quinlan and Smol, 2001), dissolved organic carbon (DOC) (Larocque et al., 2006), chlorophyll $a$ (Brodersen and Lindegaard, 1999) and lake depth (Korhola et al., 2000). These observations emphasise the over-riding influence of summer temperature on the distribution and abundance of chironomid species at the local to regional scale.

\section{The influence of other environmental variables on chironomid distribution and abundance}

Velle et al. (2010) discuss several environmental variables that can influence chironomid assemblages and potentially affect chironomid-based temperature estimates. We commend them on this discussion and agree that a better understanding of the influence of non-climatic parameters on chironomid-based temperature reconstruction is essential for further improvement of the method. However, we believe some of their discussion of how factors, such as trophic state and $\mathrm{pH}$, influence chironomid-based temperature estimates overlooks important points, so we provide a contrasting perspective on some specific issues below.

\section{Lake trophic state}

Velle et al. (2010) focus much of their discussion on the potential confounding effects of lake trophic change. They provide conceptual models that demonstrate different ways that lake trophic state and nutrient conditions may co-vary with temperature. We agree that there are situations in which it may be difficult to distinguish between responses to trophic change versus temperature, because taxa characteristic of warm waters are also often characteristic of eutrophic waters, and taxa characteristic of cold waters are also often characteristic of oligotrophic waters. Velle et al. (2010) suggest that this may be problematic for palaeoclimate reconstructions because relationships between climate and trophic variables could change over time, especially in the earliest Holocene when nutrients may have been suddenly released following deglaciation. However, Velle et al. (2010) do not provide compelling evidence that this situation is common as only two (SPA and RAT) of the ten lakes they analyse include early-Holocene chironomid assemblages that may be indicative of enhanced lake productivity during that time. More generally, there are many chironomid-inferred temperature (C-IT) records from the early Holocene that capture climatic oscillations at 11.3, 10.3, 9.3 and 8.2 ka BP (e.g. Axford et al., 2009; Brooks, 2003; Brooks and Birks, 2000; Caseldine et al., 2006; Lang et al., 2010a), in agreement with reconstructions from Greenland ice cores and other climate proxydata. These examples demonstrate that trophic influences do not obscure the response of chironomids to climate changes at those sites during the early Holocene.

One circumstance in which lake trophic state may indeed decouple from climate, and obscure the chironomid-temperature relationship, is when local human activities strongly affect the nutrient-loading of lakes and lead to trophic shifts unrelated to climate. Gathorne-Hardy et al. (2007) showed that the trophic influence of early Viking settlements in the Faroe Islands was distinguishable in the chironomid record. Conversely, GathorneHardy et al. (2009) showed that during human settlement and tree clearance on Iceland chironomid assemblages were relatively complacent but did respond to climate cooling during the 'Little Ice Age'. Similarly, Heiri and Lotter $(2003,2005)$ describe a chironomid record that was strongly affected by early human activity and the resulting lake anoxia during the Bronze Age. These studies demonstrate that human impacts can be discerned and distinguished from climate responses in chironomid records.

We would also emphasise that the correlation between lake trophic state and temperature is not as universal as suggested by Velle et al. (2010) and therefore cannot be invoked to explain all of the chironomid-temperature correlations strongly expressed in many data sets. The authors cite a data set (Brodersen and Anderson, 2002) from near Kangerlussuaq, western Greenland, which comes from a set of lakes exhibiting a wide range of catchment characteristics, in some cases strongly influenced by evaporative enrichment of nutrients, and representing a limited and unevenly distributed range of temperatures. This sampling strategy maximizes the statistical impact of lake catchment characteristics and minimizes the effect of temperature. At least partly because the warmer lakes are more affected by evaporative enrichment, nutrient concentrations in the sampled lakes were strongly correlated with temperature (Anderson et al., 2001; Brodersen and Anderson, 2002). Consequently, the calculated optima of individual chironomid taxa with respect to nutrient concentrations and temperature are necessarily correlated as well. Notwithstanding the above, an indication of the underlying strength of the temperature gradient is that it still accounted for about $20 \%$ of the variability in the chironomid assemblages reported.

Velle et al. (2010) suggest that a data set in which lake nutrient concentrations are not correlated with temperature is needed to demonstrate the chironomid-temperature relationship. Such a data set is easily constructed from available chironomid-temperature calibration data sets. For example, if the chironomid-temperature calibration data set from the European Alps (Heiri and Lotter, $2005,2010)$ is truncated to include only lakes with total phosphorus concentrations below $50 \mu \mathrm{g} / \mathrm{l}$ and July air temperatures cooler 
than $15^{\circ} \mathrm{C}$ (Figure 1a), then the relationship between lake total phosphorus and July temperature is effectively eliminated ( $r=$ $0.15, p=0.23$; Figure $1 c)$. Nevertheless, a chironomid-based inference model for reconstructing temperature can be developed from this restricted data set $(n=65)$ with an almost identical prediction error as in the original 100 lake inference model (Figure 1b) (bootstrapped error statistics of $r^{2}=0.77$ and RMSEP $=1.39^{\circ} \mathrm{C}$, compared with $r^{2}=0.89$ and RMSEP $=1.41^{\circ} \mathrm{C}$ in the full model). The reduced $r^{2}$ is related to the shorter temperature range included in the truncated model than in the full model. If the temperature optima of the chironomids are compared with the optima calculated for total phosphorus concentrations it becomes apparent that the relationship between the two is not nearly as strong as has been suggested (Figure 1c). No correlation is apparent if the optima of all taxa are examined $(r=0.04)$ and only a very weak relationship exists if only abundant taxa are examined $(r=0.26)$. This correlation occurs because cold lakes are typically nutrientpoor and therefore only a few cold-adapted chironomids can be identified in the data set that have a preference for high nutrient concentrations. However, in warmer climates there are clearly chironomids that have a wide range of preferences with respect to trophic state. (a) 16
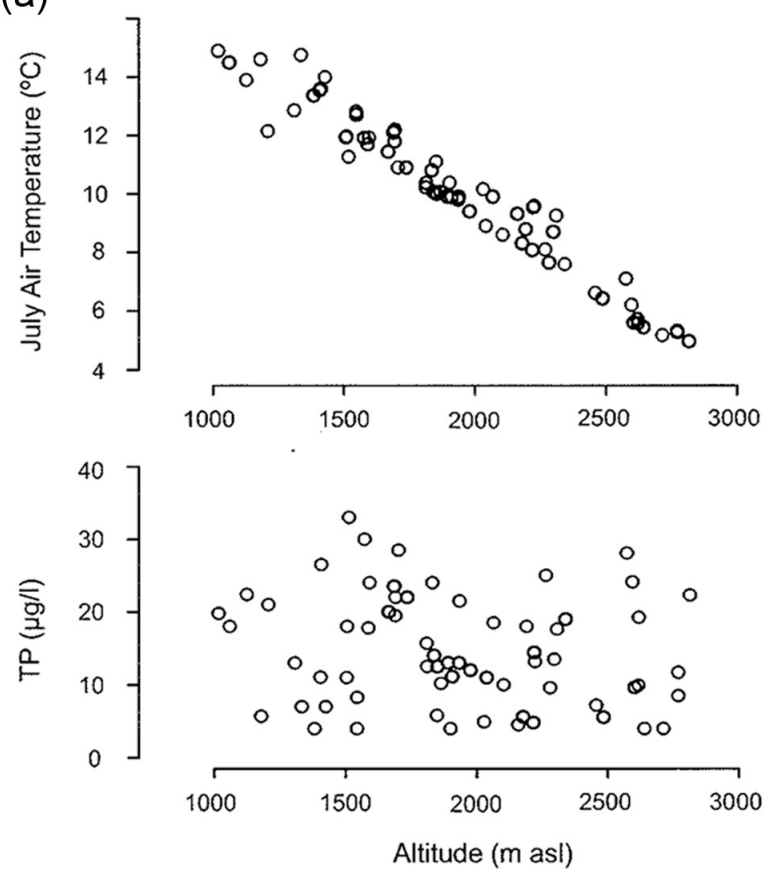

(b)

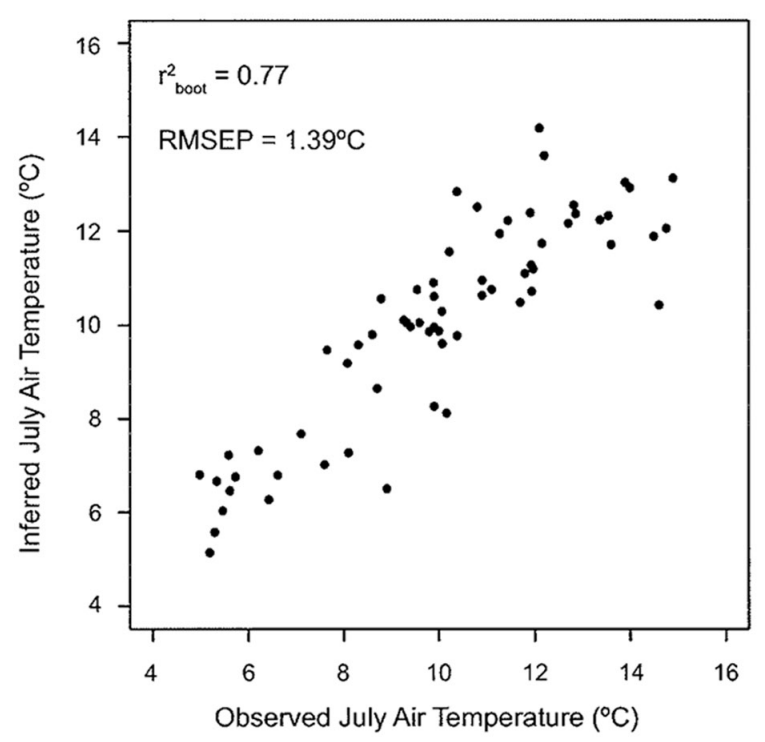

(c)

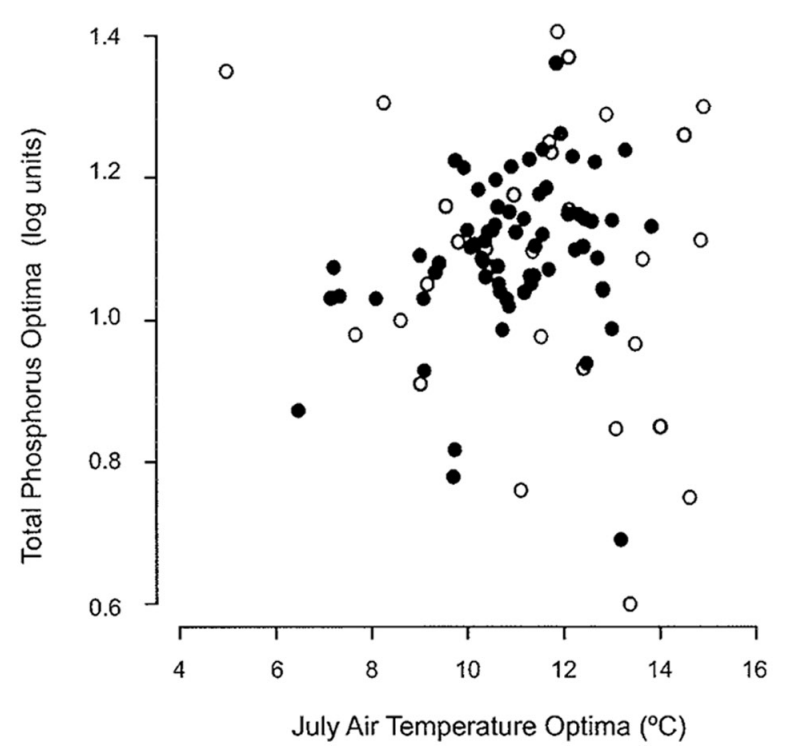

Figure I. (a) Distribution of lakes in the modern Swiss calibration set showing relationship between altitude and temperature (above) and total phosphrus (TP) (below). The calibration set has been truncated to include only lakes with total phosphorus concentrations below $50 \mu \mathrm{g} / \mathrm{l}$ and July air temperatures cooler than $15^{\circ} \mathrm{C}$. (b) Comparison of chironomid-inferred temperature and observed temperature in the truncated modern Swiss calibration set. The performance statistics of the chironomid-based temperature inference model from the truncated data set (65 lakes) are only slightly inferior to the full data set of 100 lakes. (c) Comparison of TP optima and temperature optima of the most abundant taxa (solid circles) $(r=0.26)$ and all taxa (open circles) in the truncated moderns Swiss calibration set $(r=0.04)$. 
These calculations clearly show that lake trophic state is not the driving force behind the relationship between chironomids and temperature in the European alpine region. Furthermore, since most of the chironomid taxa in the Alpine chironomid-based temperature inference model also occur in other European calibration data sets and regions, our results contradict the assertion by Velle et al. (2010) that a close correlation between temperature and nutrient optima is the rule for chironomid taxa.

\section{pH}

At pristine sites on acid bedrock a more common reason for unreliable chironomid-inferred temperature estimates than trophic change may be the influence of $\mathrm{pH}$ change. In at least two of the examples chosen by Velle et al. (2010), Gilltjärnen (GIL) and Bjørnfjelltjønn (BJØ), the strong response of chironomids to $\mathrm{pH}$ change during the mid Holocene may have reduced the reliability of the chironomid-inferred temperature estimates. Other Holocene sites that appear to have been influenced by $\mathrm{pH}$ change include Holebudalen (Velle et al., 2005) and Lochnagar (Dalton et al., 2005). These $\mathrm{pH}$ changes appear to be driven by forest or bog development in the lake catchment and so this problem could be avoided by studying lakes which remain above (or below) the treeline throughout the Holocene or which are buffered against $\mathrm{pH}$ change (e.g. carbonate lakes). The influence of $\mathrm{pH}$ on chironomid assemblages is clearly identifiable by characteristic changes in the chironomid assemblage. Acid-tolerant chironomid assemblages often include both warm and cool stenothermic taxa, although they tend to be dominated by taxa that favour the oligotrophic conditions typical of acidified lakes. As a result, many acidophilic taxa have low temperature optima and chironomid assemblages in acidified lakes may be expected to underestimate summer air temperature. This is contrary to Velle et al. (2010) who state that these assemblages will produce unrealistically high temperature estimates. This conclusion is based on an analysis by Velle et al. (2010) of the response of the warm stenothermic Microtendipes pedellus-type, which is apparently acid-tolerant in cool temperatures. However, this assertion is not supported by published data (e.g. Brodin, 1986; Dalton et al., 2005; Schnell and Willassen, 1996), which suggest that this taxon is acid intolerant, or by Woodcock et al. (2005) (referred to by Velle et al., 2010) who do not discuss any species of Microtendipes. Furthermore, our analysis of the distribution of Microtendipes pedellus-type in the modern Norwegian calibration set does not show any evidence for a positive relationship between Microtendipes pedellustype and $\mathrm{pH}$ at low temperatures (Figure 2).

Nevertheless, even in acidifying lakes, a response to temperature change may be discernable. For example, at Holebudalen, western Norway (Brooks, 2003), although the C-IT appears to underestimate summer temperature when compared to polleninferred estimates, the C-IT trends reflect falling summer insolation and the well-known temperature declines at around $4.6 \mathrm{ka}$ and $2.7 \mathrm{ka} \mathrm{BP}$ are clearly indicated (Velle et al., 2005). Similarly, at Lochnagar, Scotland, the C-IT indicates cool phases in the mid Holocene which correlate well with independent records from elsewhere in northern Britain (Langdon et al., 2004).

\section{Effects of lake depth}

Lake shallowing, which naturally occurred in many lakes during the Holocene, may result in overestimates of summer temperature as shallowing lakes become dominated by littoral and semiterrestrial taxa, which tend to have high temperature optima. Conversely, lake deepening may result in increasing abundance of profundal taxa, which tend to have cold temperature optima. Such changes are usually identifiable because of characteristic assemblage changes or can be detected by the combination of multiple

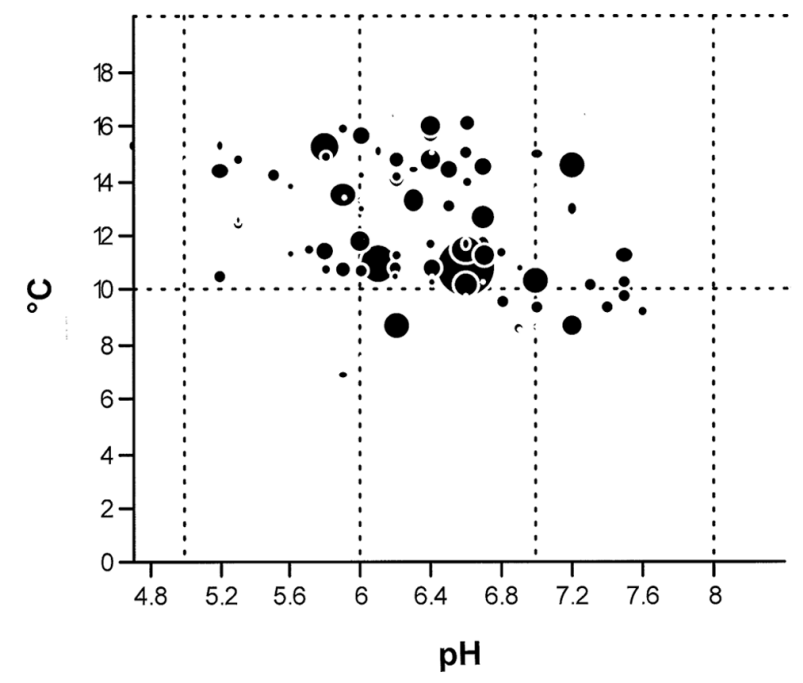

Figure 2. Mean July air temperature and $\mathrm{pH}$ of lakes in the modern Norwegian calibration set in which Microtendipes pedellustype occurs. The size of the circle is proportional to the abundance of $M$. pedellus-type in each lake.

proxies. For example, at Tsuolbmajavri (TSU) a shallowing of the lake in the late Holocene is thought to have contributed to the gradual rise in C-IT (Korhola et al., 2002). This problem was recognized in the original study, and otherwise the inferred trends from this site agree well with climate reconstructions from other independent proxies.

The C-IT from Toskaljavri, Finland (TOS) are lower than expected when considering terrestrial vegetation development at the site, and this may be because the lake is relatively deep $(21.5$ $\mathrm{m}$ ) and dominated by profundal taxa with low temperature optima. Nevertheless, the chironomid-inferred Holocene temperature trend derived from this site (Seppä et al., 2002) agrees closely with Holocene trends in the oxygen isotopes from Greenland.

\section{Taxonomic resolution}

Velle et al. (2010) suggest that taxonomic inconsistency, especially where this involves high taxonomic resolution, may lead to problems in quantitative and qualitative palaeoenvironmental interpretations. Unfortunately, they do not provide evidence to support this statement. We would argue that low taxonomic resolution is more likely to cause unreliable temperature estimates than high taxonomic resolution, given that low resolution reduces the specificity of environmental information that may be gleaned from an assemblage. As taxonomic resolution is increased, the performance of chironomid-based inference models improves (Brooks, 2006; Larocque, 2008), as does the reliability of palaeotemperature reconstructions (Heiri and Lotter, 2010). Jones (2008) also emphasises that to detect small-scale processes taxonomic resolution at species level is necessary. Given the evidence that increased taxonomic resolution can improve the reliability of chironomid-based temperature estimates, and the problems that have resulted from low resolution in the past, we encourage the pursuit and use of the highest taxonomic resolution possible.

\section{Remarks on the Scandinavian data sets}

Velle et al. (2010) state that correlation between chironomidinferred temperatures from different sites in the same climatic region should be expected if temperature has an over-riding influence and suggest this is not apparent in the Scandinavian 
sites they review. However, we caution against assuming that modern correlation of year-to-year temperature variability within an area as large as Scandinavia should indicate that decadal-scale to centennial-scale temperature variability during the Holocene would have to correlate as well. In mountainous areas, such as Norway and Sweden, and at spatial scales of hundreds to thousands of kilometres, changes in climatic forcing factors during the Holocene may well have led to differential regional climatic responses. Thus, it is not surprising that some of the records presented by Velle et al. (2010) show somewhat different reconstructed temperature patterns. However, it is notable that records from sites in close vicinity of each other do largely show consistent results, certainly within the prediction errors (about $1.0^{\circ} \mathrm{C}$ ) of the applied temperature inference models and considering the chronological uncertainties (reaching 500 years in some cases). In Iceland two closely located sites showed almost identical early-Holocene chironomid-inferred temperature histories (Caseldine et al., 2006).

\section{Conclusions}

We agree with many of the recommendations made by Velle et al. (2010). Calibration data sets and sites for downcore records should be carefully selected, chironomid-based temperature reconstruction should be undertaken within a multiproxy framework, chironomid data should be interpreted using autecological data, and fossil assemblages should be carefully evaluated for modern analogues and tested against random data (Telford and Birks, 2011). Most of these recommendations are already followed by many researchers employing chironomid-based temperature reconstructions. Several studies have incorporated multiple chironomid-based temperature records to generate robust regional palaeotemperature reconstructions (e.g. Axford et al. 2007; Caseldine et al. 2006; Lang et al., 2010b; Larocque and Hall, 2004). In many studies chironomid-based temperature reconstructions are similar to independent temperature reconstructions based on other proxies, such as glacial extent (e.g. Langdon et al., 2011; LarocqueTobler et al., 2010b), oxygen isotopes (e.g. Bedford et al., 2004; Heiri and Millet, 2005), borehole palaeothermometry (Young et al., 2011), tree rings (Clegg et al., 2010) and treeline fluctuations (Heiri et al., 2004), and are supported by results from vegetation modelling (Heiri et al., 2006) and climate models (Renssen et al., 2009).

Evidence from studies over the past 20 years in Europe and North America overwhelmingly points to summer temperature as one of the dominant drivers governing the distribution and abundance of lacustrine chironomid species in those regions. Chironomids have been used at many sites to generate Lateglacial and Holocene summer air temperature estimates that are in close agreement to independent proxy-based reconstructions and instrumental data. Unlike some temperature proxies, chironomids can be analyzed at geographically diverse and widespread sites, at high temporal resolution, and used to reconstruct both decadal-scale trends in recent centuries and millennial-scale temperature trends over long timescales. Palaeoecologists would be ill-advised to dismiss this useful method, but rather should continue to refine their understanding of this proxy and use methods, such as careful site selection and model development, multisite consensus approaches, multiproxy comparisons and analogue tests, to alleviate or detect possible complications.

\section{Acknowledgements}

We would like to thank Prof Antony Long (University of Durham, UK) for permission to refer to his unpublished re-analysis of the Kangerlussuaq, western Greenland data set.

\section{Funding}

This research received no specific grant from any funding agency in the public, commercial, or not-for-profit sectors.

\section{References}

Anderson NJ, Harriman R, Ryves DB et al. (2001) Dominant factors controlling variability in the ionic composition of West Greenland lakes Arctic, Antarctic and Alpine Research 33: 418-425.

Axford Y, Briner JP, Francis DR et al. (2011) Chironomids record terrestrial temperature changes throughout arctic interglacials of the past 200,000 years. Geological Society of America Bulletin doi: 10.1130/B30329.1.

Axford Y, Briner JP, Miller GH et al. (2009) Paleoecological evidence for abrupt cold reversals during peak Holocene warmth on Baffin Island, Arctic Canada. Quaternary Research 71: 142-149.

Axford Y, Miller GH, Geirsdóttir A et al. (2007) Holocene temperature history of northern Iceland inferred from subfossil midges. Quaternary Science Reviews 26: 3344-3358.

Bedford A, Jones RT, Lang B et al. (2004) A Late-glacial chironomid record from Hawes Water, N.W. England. Journal of Quaternary Science 19: 281-290.

Birks HJB, Heiri O, Seppä H et al. (2010) Strengths and weaknesses of quantitative climate reconstructions based on late-Quaternary biological proxies. The Open Ecology Journal 3: 68-110.

Brodersen K and Anderson NJ (2002) Distribution of chironomids (Diptera) in low arctic West Greenland lakes: Trophic conditions, temperature and environmental reconstruction. Freshwater Biology 47: 1137-1157.

Brodersen K and Lindegaard K (1999) Classification, assessment and trophic reconstruction of Danish lakes using chironomids. Freshwater Biology 42: 143-157.

Brodin Y-W (1986) The postglacial history of Lake Flarken, southern Sweden, interpreted from subfossil insect remains. Internationale Revue der gesamten Hydrobiologie 71: 371-432.

Brooks SJ (2003) Chironomidae (Insecta: Diptera). In: MacKay A, Battarbee RW and Birks HJB (eds) Global Change in the Holocene. London: Arnold, pp. 328-341.

Brooks SJ (2006) Fossil midges as palaeoclimatic indicators of the Eurasian region. Quaternary Science Reviews 25: 1894-1910.

Brooks SJ and Birks HJB (2000) Chironomid-inferred late-glacial air temperatures at Whitrig Bog, south-east Scotland. Journal of Quaternary Science 15: 759-764.

Brooks SJ and Birks HJB (2001) Chironomid-inferred air temperatures from late-glacial and Holocene sites in north-west Europe: Progress and problems. Quaternary Science Reviews 20: 1723-1741.

Brooks SJ, Bennion H and Birks HJB (2001) Tracing lake trophic history with a chironomid-total phosphorus inference model. Freshwater Biology 46: 511-532.

Caseldine C, Langdon P and Holmes N (2006) Early Holocene climate variability and the timing and extent of the Holocene thermal maximum (HTM) in northern Iceland. Quaternary Science Reviews 25: 2314-2331.

Clegg BF, Clarke GH, Chipman ML et al. (2010) Six millennia of summer temperature variation based on midge analysis of lake sediments from Alaska. Quaternary Science Reviews 29: 3308-3316.

Dalton C, Birks HJB, Brooks SJ et al. (2005) A multiproxy study of lakedevelopment in response to catchment changes during the Holocene at Lochnagar, north-east Scotland. Palaeogeography, Palaeoclimatology, Palaeoecology 221: 175-201.

Gathorne-Hardy FJ, Erlendsson E, Langdon PG et al. (2009) Lake sediment evidence for late-Holocene climate change and landscape erosion in western Iceland. Journal of Paleolimnology 42: 413-426.

Gathorne-Hardy FJ, Lawson IT, Church MJ et al. (2007) The impact of the Norse Landnám on the Chironomidae (Insecta: Diptera) of lake Gróthúsvatn, Sandoy, Faroe Islands. The Holocene 17: 1259-1264.

Hann BJ, Warner BG and Warwick WF (1992) Aquatic invertebrates and climate change: A comment on Walker et al. (1991). Canadian Journal of Fisheries and Aquatic Sciences 49: 1274-1276.

Heiri C, Bugmann H, Tinner W et al. (2006) A model-based reconstruction of Holocene treeline dynamics in the Central Swiss Alps. Journal of Ecology 94: 206-216.

Heiri O and Lotter AF (2003) 9000 years of chironomid assemblage dynamics in an Alpine lake: Long-term trends, sensitivity to disturbance, and resilience of the fauna. Journal of Paleolimnology 30: 273-289.

Heiri O and Lotter AF (2005) Holocene and Lateglacial summer temperature reconstruction in the Swiss Alps based on fossil assemblages of aquatic organisms: A review. Boreas 34: 506-516. 
Heiri O and Lotter AF (2010) How does taxonomic resolution affect chironomidbased temperature reconstruction? Journal of Paleolimnology 44: 589-601.

Heiri O and Millet L (2005) Reconstruction of Late Glacial summer temperatures from chironomid assemblages in Lac Lautrey (Jura, France). Journal of Quaternary Science 20: 33-44.

Heiri O, Cremer H, Engels S et al. (2007) Lateglacial summer temperatures in the Northwest European lowlands: A chironomid record from Hijkermeer, the Netherlands. Quaternary Science Reviews 26: 2420-2437.

Heiri O, Tinner W and Lotter AF (2004) Evidence for cooler European summers during periods of changing meltwater flux to the North Atlantic. Proceedings of the National Academy of Sciences 101: 15,285-15,288.

Jones FC (2008) Taxonomic sufficiency: The influence of taxonomic resolution on freshwater bioassessmernts using benthic macroinvertebrates. Environmental Reviews 16: 45-69.

Korhola A, Olander H and Blom T (2000) Cladoceran and chironomid assemblages as quantitative indicators of water depth in subarctic Fennoscandian lakes. Journal of Paleolimnology 24: 43-54.

Korhola A, Vasko K, Toivonen HTT et al. (2002) Holocene temperature changes in northern Fennoscandia reconstructed from chironomids using Bayesian modelling Quaternary Science Reviews 21: 1841-1860.

Lang B, Bedford A, Brooks SJ et al. (2010a) Early-Holocene temperature variability inferred from chironomid assemblages at Hawes Water, northwest England. The Holocene 20: 943-954.

Lang B, Brooks SJ, Bedford A et al. (2010b) Regional consistency in Lateglacial chironomid-inferred temperatures from five sites in north-west England. Quaternary Science Reviews 29: 1528-1538.

Langdon PG, Barber KE and Lomas-Clarke SH (2004) Reconstructing climate and environmental change in northern England through chironomid and pollen analyses: Evidence from Talkin Tarn, Cumbria. Journal of Paleolimnology 32: 197-213.

Langdon PG, Caseldine CJ, Croudace IW et al. (2011) A chironomid-based reconstruction of summer temperatures in NW Iceland since AD 1650. Quaternary Research 75: 451-460.

Langdon PG, Ruiz Z, Brodersen KP et al. (2006) Assessing lake eutrophication using chironomids: Understanding the nature of community response in different lake types. Freshwater Biology 51: 562-577.

Larocque I (2008) Nouvelle fonction de transfert pour reconstruire la température à l'aide des chironomides préservés dans les sédiments lacustres. INRS Rapport de Recherche R1032, ISBN 978-2-89146-587-8.

Larocque I and Hall RI (2003) Chironomids as quantitative indicators of mean July air temperature: Validation by comparison with century-long meteorological records from northern Sweden. Journal of Paleolimnology 29: 475-493.

Larocque I and Hall RI (2004) Holocene temperature estimates and chironomid community composition in the Abisko Valley, northern Sweden. Quaternary Science Reviews 23: 475-493.

Larocque I, Grosjean M, Heiri O et al. (2009) Comparison between chironomidinferred July temperatures and meteorological data AD 1850-2001 from varved Lake Silvaplana, Switzerland. Journal of Paleolimnology 41: 329-342.

Larocque I, Hall RI and Grahn E (2001) Chironomids as indicators of climate change: A 100-lake training set from a subarctic region of northern Sweden (Lapland). Journal of Paleolimnology 26: 307-322.
Larocque I, Pienitz R and Rolland N (2006) Factors influencing the distribution of chironomids in lakes distributed along a latitudinal gradient in northwestern Quebec, Canada. Canadian Journal of Fisheries and Aquatic Sciences 63: 1286-1297.

Larocque-Tobler I, Grosjean M, Heiri O et al. (2010b) Thousand years of climate change reconstructed from chironomid subfossils preserved in varved lake Silvaplana, Engadine, Switzerland. Quaternary Science Reviews 29: 1940-1949.

Larocque-Tobler I, Heiri O and Wehrli M (2010a) Late glacial and Holocene temperature changes at Egelsee, Switzerland, reconstructed using subfossil chironomids. Journal of Paleolimnology 43: 649-666.

Levesque AJ, Mayle FE, Walker IR et al. (1993) A previously unrecognised late-glacial cold event in eastern North America. Nature 361: 623-626.

Lotter AF, Birks HJB, Hofmann W et al. (1997) Modern diatom, Cladocera, chironomid, and chrysophyte cyst assemblages as quantitative indicators for the reconstruction of past environmental conditions in the Alps. I. Climate. Journal of Paleolimnology 18: 395-420.

Olander H, Birks HJB, Korhola A et al. (1999) An expanded calibration model for inferring lakewater and air temperatures from fossil chironomid assemblages in northern Fennoscandia. The Holocene 9: 279-294.

Quinlan R and Smol JP (2001) Chironomid-based inference models for estimating end-of-summer hypolimnetic oxygen from south-central Ontario shield lakes. Freshwater Biology 46: 1529-1551.

Renssen H, Seppä H, Heiri O et al. (2009) The spatial and temporal complexity of the Holocene thermal maximum. Nature Geoscience 2: 410-413.

Schnell OA and Willassen E (1996) The chironomid (Diptera) communities in two sediment cores from Store Hovvatn, S. Norway, an acidified lake. Annales de Limnologie 32: 45-61.

Seppä H, Nyman M, Korhola A et al. (2002) Changes of treelines and alpine vegetation in relation to post-glacial climate dynamics in northern Fennoscandia based on pollen and chironomid records Journal of Quaternary Science 17: 287-301.

Telford RJ and Birks HJB (2011) A novel method for assessing the statistical significance of quantitative reconstructions inferred from biotic assemblages. Quaternary Science Reviews 30: 1272-1278.

Velle G, Brooks SJ, Birks HJB et al. (2005) Chironomids as a tool for inferring Holocene climate: An assessment based on six sites in southern Scandinavia. Quaternary Science Reviews 24: 1429-1462.

Velle G, Brodersen KP, Birks HJB et al. (2010) Midges as quantitative temperature indicator species: Lessons for palaeoecology. The Holocene 20: 989-1002.

Walker IR and Mathewes RW (1989) Much ado about dead Diptera. Journal of Paleolimnology 2: 19-22.

Warwick WF (1989) Chironomids, lake development and climate: A commentary. Journal of Paleolimnology 2: 15-17.

Woodcock T, Longcore J, McAuley D et al. (2005) The role of pH in structuring communities of Maine wetland macrophytes and chironomid larvae (Diptera). Wetlands 25: 306-316.

Young NE, Briner JP, Stewart HAM et al. (2011) Response of Jakobshavn Isbræ, Greenland, to Holocene climate change. Geology 39: 131-134. 


\title{
Inconsistent results should not be overlooked: A reply to Brooks et al. (20 I 2)
}

(C) The Author(s) 2012

Reprints and permission:

sagepub.co.uk/journalsPermissions.nav DOI: I0.1 I77/09596836/2449765

hol.sagepub.com

@SAGE

\author{
G Velle,' KP Brodersen, ${ }^{2}$ HJB Birks ${ }^{3,4,5}$ and E Willassen ${ }^{6}$
}

\begin{abstract}
Empirical data in the form of many chironomid-based temperature reconstructions give an excellent opportunity to assess the chironomid approach to temperature reconstruction by testing its reproducibility. Brooks et al. (The Holocene 22(I2) 2012 (this issue)) offer a critique of points discussed in Velle et al. (The Holocene 20 (2010) 989-1002), but fail to explain the poor reproducibility found when Holocene chironomid-based temperature reconstructions are compared. We discuss the issues raised by Brooks et al. (2012) and cite studies that demonstrate the complexity involved. We are grateful to Brooks et al. (2012) for contributing to the discussion. However, they overly rely uncritically on transfer functions and the resulting reconstructions as representatives of true patterns in nature. A major source of bias involved when chironomids are used as a palaeoenvironmental proxy is the response to confounding gradients. Many of the challenges discussed in the Forum Article, in the comment, and in the reply are also valid for other research fields within palaeoecology. The challenges should still be properly addressed in chironomid research.
\end{abstract}

\section{Keywords}

chironomids, confounding gradients, palaeoenvironmental proxies, reconstruction validation, temperature, training-set

Received 22 February 2012; revised manuscript accepted 29 February 2012

\section{Validation of results}

\section{Inconsistent temperature reconstructions}

As Brooks et al. (2012) note, Velle et al. (2010a) have re-opened a 20 year old debate on biological indicators. Twenty years ago there was an active discussion about whether chironomid assemblages are reliable indicators of past temperatures. There is, however, one important difference between the situation today and 20 years ago. Now, there are empirical data in the form of many chironomidbased temperature reconstructions. So far, more than 20 Holocene chironomid-based temperature reconstructions have been published from Norway, Sweden, and Finland (Antonsson et al., 2006; Bigler et al., 2002, 2003; Heider, 2004; Heinrichs et al., 2005; Korhola et al., 2002; Larocque and Bigler, 2004; Lüder, 2007; Luoto et al., 2010; Paus et al., 2011; Seppä et al., 2002; Velle et al., 2005a, 2005b, 2010b, 2011). Many more have been published worldwide. The Velle et al. (2010a) Forum Article was written to shed light on a striking problem that empirical data and reconstructions have revealed: when Holocene temperature reconstructions from different sampling localities are compared there are many instances of strongly mismatching curves (Figure 1). We feel that many investigators have overlooked this problem and we hope that our Forum Article and ensuing discussion and research would contribute towards resolving the problem. Similarities with other proxies or multiple sites are needed to confirm results, but the results are too uncertain to assess whether discordances are real or are caused by confounding factors.

Velle et al. (2010a) show ten reconstructions and argue that these are so different that it seems unlikely they can solely be attributed to local site differences in microclimate. Brooks et al. (2012) caution against assuming that decadal-scale to centennialscale temperature variability in Scandinavia should correlate. However, studies of the instrumental record of the last 100-250 years (Casty et al., 2007; Dobrovolny et al., 2010; Jones and Moberg, 2003; Luterbacher et al., 2004; Meier et al., 2007;
Moberg et al., 2005; Nordli et al., 2003) and of reconstructions from documentary proxy evidence during the last 500 years (Brazdil et al., 2010; Casty et al., 2005; Dobrovolny et al., 2010; Meier et al., 2007) suggest that temperatures do correlate, not only in Scandinavia, but also across Europe. Brooks et al. (2012) are rightly concerned that chronological uncertainties can obscure a comparison between sites. In a study on six Holocene chironomid-stratigraphies, Velle et al. (2005a) tested the numerical relationship among unsmoothed and smoothed inferred temperature curves. Since only two of 15 comparisons were statistically significantly positively correlated, uncertainties associated with chronologies were tested. The correlation analysis indicated no correlation, whereas by disregarding the dating model, there was series of matching temperatures events, but only when the original age-depth models were displaced by more than 1000 years (Velle et al., 2005a: figure 11). In this context, it is of little meaning to search for discordances that are, or are not, within the prediction errors of the temperature inferences, as Brooks et al. (2012) do. At many sites, the chironomid-inferred temperatures are too erratic to be climatically useful. For most sites, it is of little

\footnotetext{
'Uni Environment, Uni Research, Norway

${ }^{2}$ klausbrodersen.dk, Denmark

${ }^{3}$ University of Bergen, Norway

${ }^{4}$ University College London, UK

5University of Oxford, UK

${ }^{6}$ University Museum of Bergen, University of Bergen, Norway
}

Corresponding author:

G Velle, Uni Environment, Uni Research, Thormøhlensgate 49B, 5006 Bergen, Norway.

Email: gaute.velle@bio.uib.no 


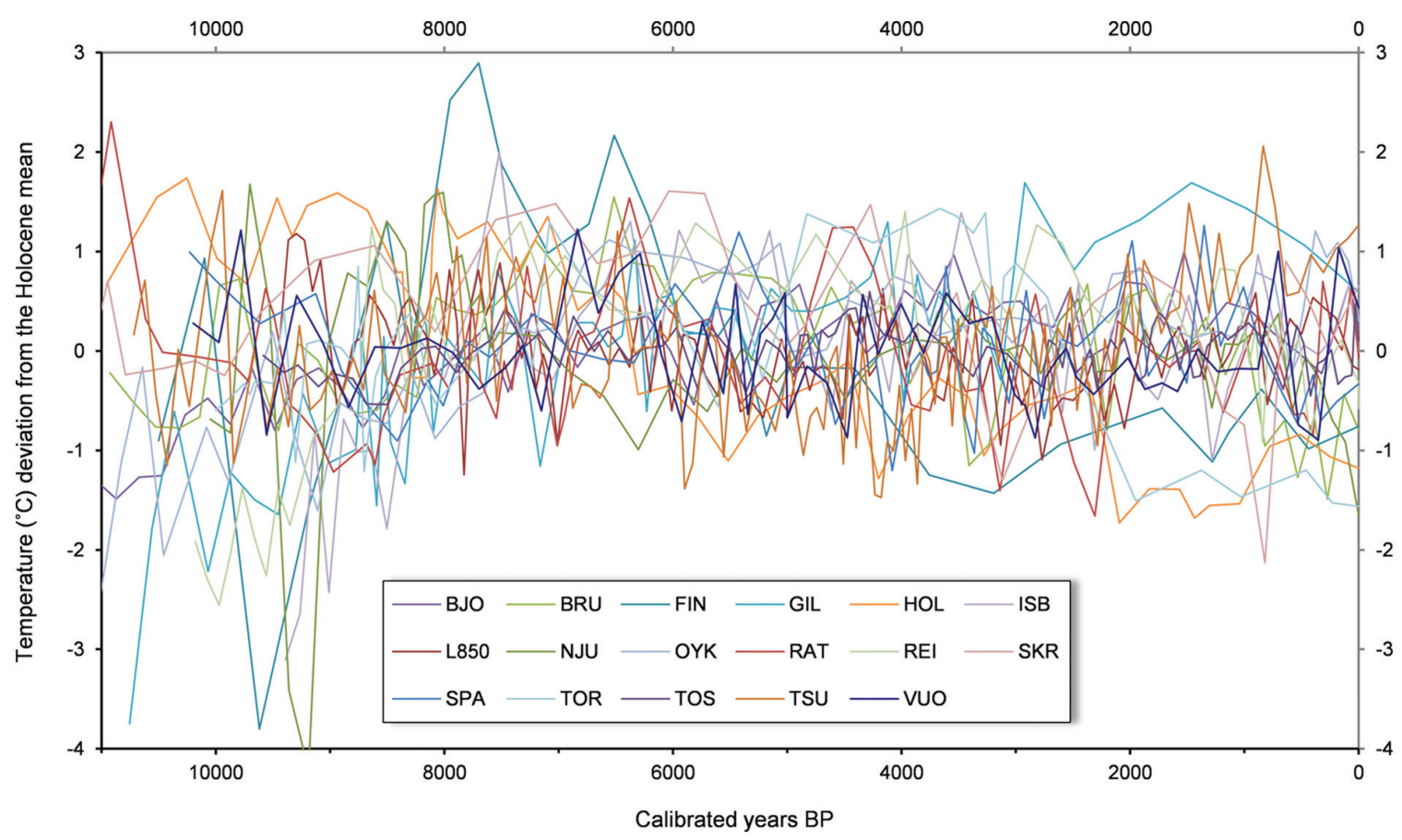

Figure I. Chironomid-inferred mean July air temperatures adjusted for glacioisostatic rebound. BJO: Bjørnfjelltjønn (Brooks, 2006); BRU: Brurskardet (Velle et al., 20 I0b); FIN: Finse Stasjonsdam (Velle et al., 2005a); GIL, Gilltiärnen (Antonsson et al., 2006); HOL, Holebudalen (Velle et al., 2005a); ISB: Isbenttjønn (Lüder, 2007); L850: Lake 850 (Larocque and Bigler, 2004); NJU: Njulla (Bigler et al., 2003); OYK:Vestre Økjamyrtjønn (Velle et al., 2005a); RAT: Råtåsjøen (Velle et al., 2005b); REl: Reiardalsvatnet (Lüder, 2007); SKR: Stora Kroksjön (Heider, 2004); SPA: Spåime (Hammarlund et al., 2004);TOR: Lilla Torkelsjön (Heider, 2004);TOS:Toskaljavri (Seppä et al., 2002);TSU:Tsuolbmajavri (Korhola et al., 2002);VUO: Vuoskkujávri (Bigler et al., 2002).

value to interpret temperature fluctuations that are inside the prediction errors estimated by statistical cross-validation, as many chironomid workers continue to do.

Strong differences prevail when more sites than those presented in Velle et al. (2010a) are included in the comparison (i.e. three sites from western Norway (Velle et al., 2005a), two from southern Norway (Lüder, 2007), and two from southern Sweden (Heider, 2004); Figure 1). Chironomids have produced encouraging results (Larocque et al., 2009), but there is no doubt that chironomids have also produced discouraging results Norway (Velle et al., 2005a). In all instances, quantitative proxies will only produce reliable estimates of past environmental conditions with robust errors if the assumptions of the reconstruction method are met (Birks et al., 2010). While Brooks et al. (2012) make some valuable comments, they fail to acknowledge the underlying concern of Velle et al. (2010a): Why are the chironomid-inferred Holocene temperatures from Fennoscandia so different? We have initiated a re-analysis of most chironomid data sets from Norway, Sweden, Finland, Iceland, and UK. This is a joint project, including some of the Comment authors and others, which hopefully will help to identify at what sites and at what periods the chironomid approach is reliable (e.g. Figure 2).

\section{Validation with instrumental records}

As Brooks et al. (2012) point out, chironomids have been assessed as a palaeoclimatic proxy by comparing the reconstructed temperatures with instrumental records for the last 100-150 years. This validation has given promising results, but studies that failed to find a correlation between chironomids and the instrumental temperature record should not be overlooked (e.g. Axford et al., 2009; Cameron et al., 2002; Lotter et al., 2002). In addition, it is important to consider potential confounding factors when downcore chironomids and the instrumental temperature record are compared: (1) Any comparison and numerical correlation should be corrected for temporal auto-correlation, as there is a lack of statistical independence in the fossil record and in the instrumental record (Tian et al., 2011). The auto-correlation violates the assumptions of many statistical tests and can cause overoptimistic estimates of the correlation coefficient. A correction for autocorrection is usually not performed in chironomid-temperature validation, but as Tian et al. (2011) show, such a correction can easily be achieved using a block bootstrap similar to $h$-block cross-validation (Burman et al., 1994). (2) A correlation during the instrumental record for the last 100-150 years does not imply that the chironomid record will provide reliable temperatures for the entire Holocene. This was very evident in Lake 850 in Sweden. Here, there was a good match between the instrumental record and inferred temperatures for the last 100 years (Larocque and Hall, 2003). However, based on inconsistencies in a Holocene multiproxy study, Larocque and Bigler (2004) concluded that temperature was not the most important factor to explain the distribution and abundance of chironomids prior to $2500 \mathrm{cal}$. yr BP.

\section{Validation with independent proxies}

Brooks et al. (2012) cite studies where results obtained from chironomids correspond well with the results obtained from other proxies or with independent records, such as the Greenland icecores. We agree that a comparison with independent records is a principal assessment of results. However, we note the following: (1) it is unclear to us why Brooks et al. (2012) assume that temperatures throughout Scandinavia should not necessarily correlate, while Scandinavian chironomid temperature reconstructions should correlate with ice-core records from Greenland. (2) We caution against the risk of circularity of argument. In their conclusions, Brooks et al. (2012) write that chironomid-based temperature reconstructions are supported by results from vegetation 

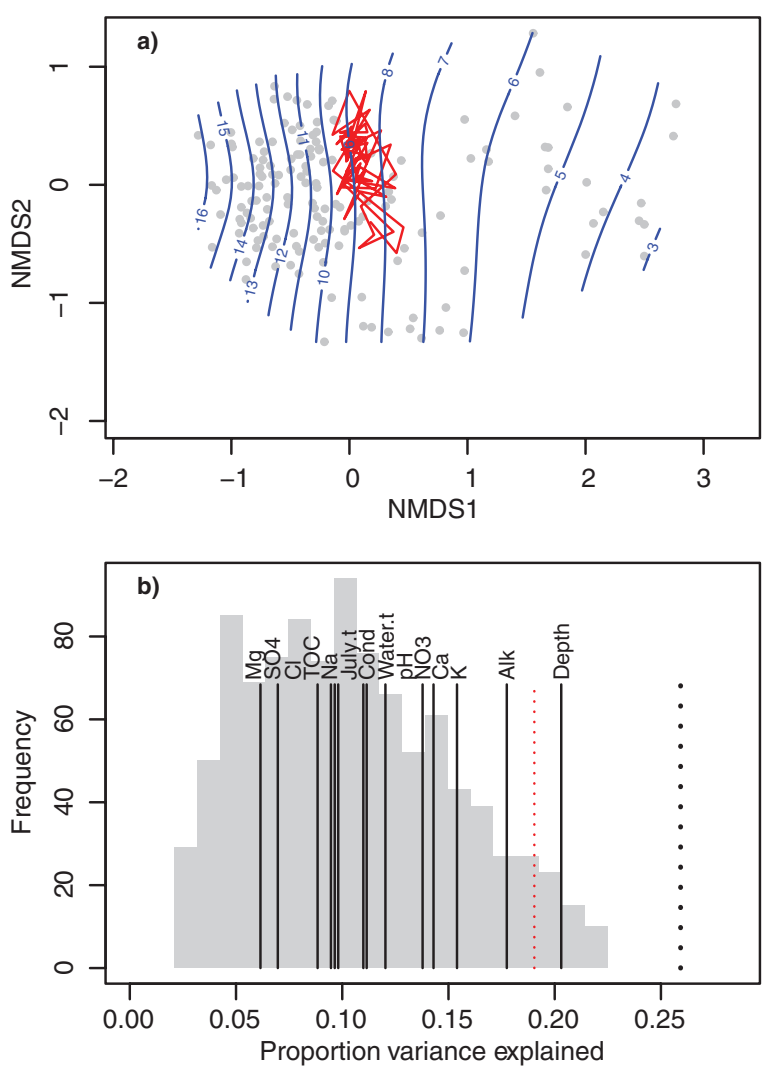

Figure 2. (a) Non-metric multidimensional scaling (NMDS) of fossil chironomids from Råtåsjøen (red line) added passively into the NMDS space of samples in the modern Norwegian calibration data set (grey dots). The contours (blue) represent temperature change $\left({ }^{\circ} \mathrm{C}\right.$ ) of samples in the Norwegian calibration data set (Brooks and Birks, 200I, unpublished data, 200I-20I0). The fossil samples change along some unknown secondary gradient, NMDS2. (b) Proportion of variance in the Rååajøen fossil data explained by environmental variables in the modern calibration data set. The only statistically significant environmental variable is lake depth, suggesting that the secondary gradient found from the NMDS is lake depth. The dashed line to the far right shows the proportion explained by the first axis of a PCA, while the red dashed line shows the threshold from which the environmental variables explains more of the variance than $95 \%$ of 999 random reconstructions. For details on the method, see Telford and Birks (2011).

modelling. A correlation between inferred temperatures and vegetation modelling is not surprising given that the vegetation model they cite (Heiri et al., 2006) was driven by chironomid-inferred temperatures. Our interpretation is that Brooks et al. (2012) find the chironomid-inferred temperatures supported since the chironomid temperature-driven vegetation model produced vegetation dynamics that mimic an independent pollen record. (3) A general visual similarity with independent climate proxies should also be quantified and assessed for statistical significance (e.g. Dobrovolny et al., 2010: figure 6). According to Bennett (2002), testable hypotheses are needed or it becomes difficult or impossible to disentangle what is based on data and what is based on opinions. (4) There are many multiproxy studies that have pointed out inconsistencies between temperatures obtained from chironomids and other proxies, or studies that have suggested temperature was not the main driver for the full or parts of the down-core chironomid distribution (Bigler et al., 2002; Dalton et al., 2005; Heinrichs et al., 2005; Heiri and Lotter, 2003; Heiri et al., 2003; Korhola et al., 2002; Larocque and Bigler, 2004; Lüder, 2007; Nyman et al., 2008; Velle et al., 2010b).

\section{Gradient length and response to confounding variables}

\section{Gradient length in training-sets}

We do not think that chironomids are a useful proxy for any environmental variable provided the gradient is long enough, as Brooks et al. (2012) give the impression that we do. However, based on training-set statistics, any environmental variable will appear to be reconstructable if the gradient is long enough and other gradients are short. This is demonstrated by the many environmental variables that chironomids appear to respond to in training-sets (Table 1).

Brooks et al. (2012) state that the performance statistics of chironomid-based temperature inference models exceeds by far the performance statistics of other chironomid-based models. We agree that the numerical performance of chironomid-based temperature-inference models is good (Table 1), but miss data from Brooks et al. (2012) that confirm their statement. To our knowledge it has not been tested whether temperature-inference models out-perform the numerical performance of training-sets based on other environmental variables. The coefficient of determination $\left(r^{2}\right)$ measures the strength of the relationship between observed and predicted values and will increase with gradient length, while RMSEP and bias statistics are not dependent on the range of the observed environmental gradient (Birks, 1998). Different units of measurement (e.g. chlorophyll $a(\mu \mathrm{g} / \mathrm{l})$, water depth (m) or temperature $\left({ }^{\circ} \mathrm{C}\right)$ ) are not comparable unless standardised. Hence, a comparison among training-sets based on dissimilar environmental variables is valid if the gradient lengths are similar and the environmental data are standardised to a comparable unitless scale.

\section{Relationship to temperature}

Most chironomid-temperature training-sets show significant responses to temperature and to secondary variables, such as organic carbon, alkalinity, conductivity, solar radiation, magnesium, precipitation, altitude, lake depth, and lake productivity (e.g. Barley et al., 2006; Larocque et al., 2001, 2006; Lotter et al., 1997, 1998; Olander et al., 1999; Rees et al., 2008; Velle et al., 2005a). In surprisingly many training-sets designed for long temperature gradients, the response to environmental variables other than temperature overrides the response to temperature. Such variables include $\mathrm{pH}$ (Porinchu et al., 2009; Rees et al., 2008), loss-on-ignition (LOI) (Larocque et al., 2001; Olander et al., 1999), lake depth (Porinchu et al., 2009), total carbon (Langdon et al., 2008), or total nitrogen (Porinchu et al., 2009). Chironomids in data sets that are not designed for training-set purposes will respond most significantly to one of several environmental variables, such as tropho-dynamic status, DOC, sediment organic content, chlorophyll $a$, bottom oxygen content, lake size, location of the lake, water chemistry, or altitude (Bigler et al., 2006; Brodersen and Lindegaard, 1999; Catalan et al., 2009; Fjellheim et al., 2009; Kernan et al., 2009; Nyman et al., 2005; Real and Prat, 1992). Many of these environmental variables co-vary with temperature or with one or more of the other variables listed above.

There is a lack of understanding on the relationship between chironomids and temperature, and it seems that indirect effects of temperature can play an important role (Eggermont and Heiri, 2011). When this is the case, it is wise to interpret down-core reconstructions cautiously. All training-sets will produce results when applied down-core (Birks et al., 2010). Can chironomids provide reliable estimates for temperature change or for change along any of the other environmental variables from training-sets (Table 1) backwards in time? In principle yes, but only if the environmental variable of interest is the dominating gradient at the 
Table I. Examples of chironomid training-sets developed to infer diverse environmental variables.

\begin{tabular}{|c|c|c|c|c|c|}
\hline Environmental variable & Region & $\lambda 1 / \lambda 2$ & Model & $r_{\text {jack }}^{2}$ & Reference \\
\hline July temperature & Sweden & & $W A_{\text {inv }}$ & 0.44 & Rosén et al. (200I) \\
\hline July temperature & Norway and Switzerland & 1.17 & WA-PLS 2 & 0.87 & Heiri et al. (20II) \\
\hline Water T & Sierra Nevada, USA & 0.87 & $W_{\text {classical }}$ & 0.73 & Porinchu et al. (2002) \\
\hline Water depth & Finland & 0.68 & PLS 2 & 0.70 & Korhola et al. (2000) \\
\hline Total phosphorus & UK & 1.21 & $\mathrm{WA}_{\mathrm{inv}}$ & 0.60 & Brooks et al. (200I) \\
\hline Salinity & Tibetan plateau & 0.73 & WA-PLS 2 & 0.80 & Zhang et al. (2007) \\
\hline Late summer anoxia & Ontario, Canada & 0.40 & $W_{\text {inv tol }}$ & 0.56 & Quinlan and Smol (200I) \\
\hline Late winter anoxia & Southern Finland & 0.77 & WA-PLS I & 0.72 & Luoto and Salonen (2010) \\
\hline Stream flow/turbulence & Finland, intra-lake & 0.95 & $\mathrm{WA}_{\text {classical }}$ & 0.77 & Luoto $(2010)$ \\
\hline Chlorophyll $a$ & Denmark & 1.38 & $W A_{\text {inv }}$ & 0.67 & Brodersen and Lindegaard (1999) \\
\hline Continentality & Russia and Norway & 0.48 & WA-PLS 2 & 0.73 & Self et al. $(20 \mathrm{II})$ \\
\hline $\begin{array}{l}\text { Distance to littoral } \\
\text { vegetation }\end{array}$ & Finland, intra-lake & 0.77 & $\mathrm{WA}_{\text {classical }}$ & 0.71 & Luoto $(2010)$ \\
\hline $\mathrm{pH}$ & Tasmania & 0.90 & WA-PLS I & 0.74 & Rees and Cwynar (20I0) \\
\hline
\end{tabular}

For reference on model performance, the average $r_{\text {jack }}^{2}$ for 23 published chironomid-air temperature training-sets is 0.75 . WA: weighted averaging; PLS: partial least squares;WA-PLS: weighted averaging partial least squares; inv: inverse deshrinking; classical: classical deshrinking; tol: tolerance downweighting. The number after WA-PLS refers to the number of WA-PLS components considered.

time of interest (Birks et al., 2010). Many chironomid researchers have been concerned about issues of confounding gradients. Brooks (2006) stressed that soil development and the resulting changes in $\mathrm{pH}$, nutrients, dissolved oxygen (DO), and dissolved organic carbon (DOC) can have a greater influence than temperature on the composition of some midge assemblages. Larocque et al. (2006) suggested that it was hard to dissociate the combined effects of temperature, DOC, LOI, and depth when performing down-core temperature reconstructions. According to Langdon et al. (2008) it is a major challenge to separate the effects of temperature, LOI, and lake depth on subfossil chironomid sequences.

\section{Correlation between temperature optima and trophic optima}

Brooks et al. (2012) agree that taxa characteristic of warm waters are also often characteristic of eutrophic waters, and taxa characteristic of cold waters are also often characteristic of oligotrophic waters. However, based on optima in a truncated data set they argue the correlation between trophic optima and temperature is not as universal as we suggested. First, we point out that a relationship between trophic optima and temperature optima should not be expected for all taxa in a data set since the optima for rare taxa are inevitably poorly defined. Only common taxa are relevant and performing a more robust correlation with outliers removed would drastically improve the correlation (see Brooks et al., 2012: figure 1). Second and most important, concerning the relationship between temperature and trophic status (nutrients, chlorophyll, Secchi-depth, DOC), it is not a matter of our opinion, or of transfer-function performance and statistical prediction errors, but a question of well-described ecological and limnological phenomena in nature (Brodersen and Anderson, 2002; Brodersen and Lindegaard, 1999; Brooks et al., 2001; Brundin, 1949, 1956; Lenz, 1925; Lotter et al., 1997; Sæther, 1979; Thienemann, 1928, 1954; Walker et al., 1991; Wiederholm and Erikson, 1979). Several examples of significant positive correlations between temperature and trophic variables are reviewed by Eggermont and Heiri (2011). These relationships are responsible for the evolutionary outcome that warm-water taxa, with a higher metabolic activity, are also adapted to productive lakes (and streams, see Velle et al., 2010a: figure 6) rich in available food for growth. This should not be
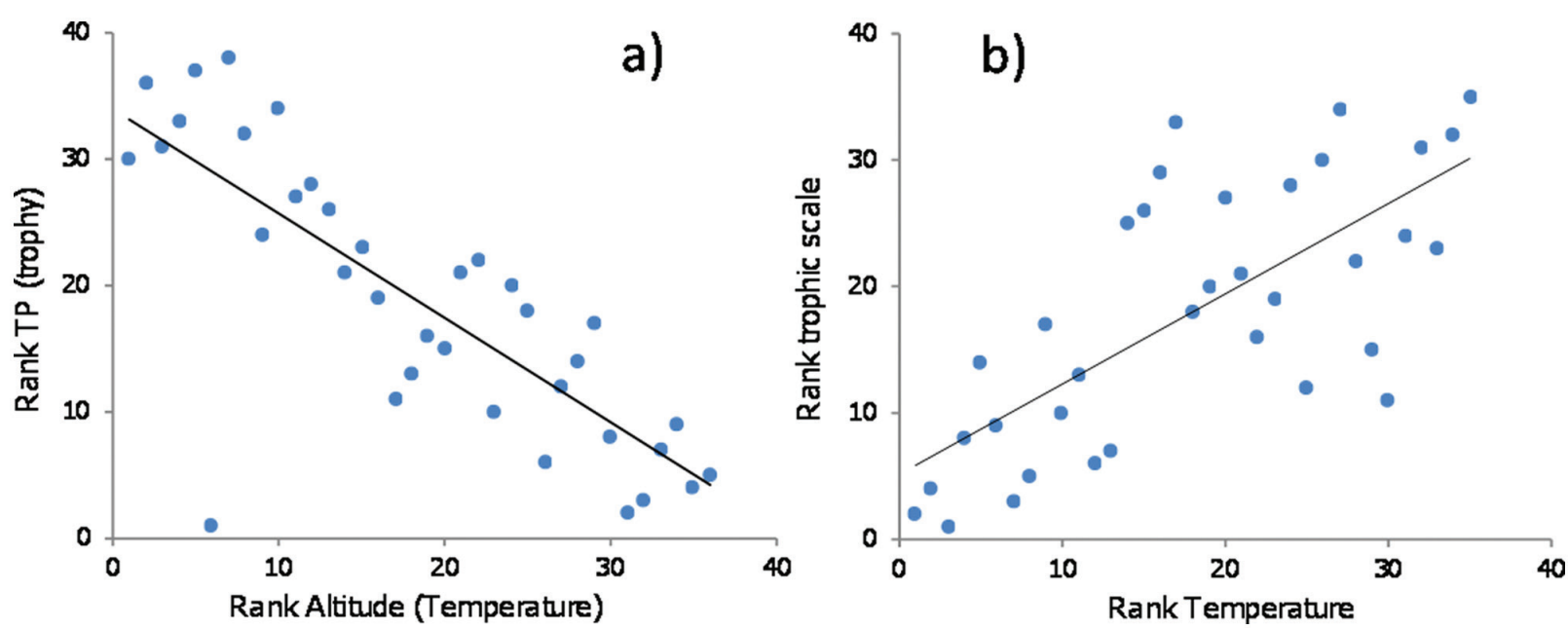

Figure 3. (a) Rank correlation between chironomid altitudinal optima in the Swiss Alps (Lotter et al., 1997: figure 6) and trophic optima (Lotter et al., 1998: figure 6). The correlation between temperature and total phosphorus (TP) in the Swiss Alps is $r=0.57, p<0.01$ in the non-truncated data set. (b) Rank correlation between chironomid temperature optima for northwest North America (Barley et al., 2006) and trophic rank (Sæther, 1979). Average rank numbers for trophy were used where adjustment to subfossil genus/type was necessary. 
surprising and can be shown for many data sets (Figure 3a). Comparison of independent data will, in many cases, give the same rather convincing result (Figure 3b). However, even if we could succeed in selecting lakes to produce the ideal training-set with no correlations among the variables, as Brooks at al. (2012) attempt, nature will still expose the same relationship based on all the thousands of lakes that were not sampled for the optimised data set. Modern data sets aimed and designed for high precision and accuracy for single variables may perform well for that purpose, but will not necessarily reflect the true complexity in nature in space and time because they are optimised for a single variable at one point in time. If this ecological knowledge is acknowledged, it can be used positively to understand palaeoecological records and contradictions in inferred environmental variables.

\section{Trophic optima in a Greenland data set}

Velle et al. (2010a) cite a study from West Greenland where B rodersen and Anderson (2002) demonstrate there is a strong correlation between temperature optima and trophic optima. Brooks et al. (2012) argue that the West Greenland data set maximises the statistical impact of lake catchment characteristics (nutrients) and minimises the impact of temperature. If Brooks et al. (2012) see this as a problem, we point out that such a sampling strategy with single environmental gradients maximised is common in chironomid temperature training-sets and other proxy-based training-sets (e.g. Brooks and Birks, 2001). Brodersen and Anderson (2002) realised that the nutrient gradient in the Greenland data was long and that temperature significantly explained $20 \%$ of the variation in the chironomid data. However, instead of publishing a seemingly good temperature transfer function, they attempted to interpret ecologically the multivariate complexity in their data set. Theoretically, Brodersen and Anderson (2002) could have maximised the temperature gradient simply by including an artificial climate gradient uphill. This would have been a classic example of a data set that would have obscured the strong local influence of catchment characteristics, and have ignored the true limnological processes that probably also occurred in the lakes (down-core) over the Holocene in that region.

\section{Trophic influence down-core}

Brooks et al. (2012) provide examples of sites where trophic influence is thought not to obscure the response of chironomids to climate change during the early Holocene, and argue that trophic influence is therefore not a problem. We agree that sites with small confounding gradients are ideal candidates for quantitative palaeoecology (see Velle et al., 2010a: figure 5). However, it is important to be cautious with samples from the early Holocene and from sites formed in recent deglaciations given (1) the relationship between chironomid temperature optima and trophic optima (Figure 3) (Brodersen and Anderson, 2002; Velle et al., 2010a), and (2) that leaching and lake-catchment nutrientontogeny is a natural process following deglaciation (Boyle, 2007; Engstrom and Fritz, 2006; Engstrom et al., 2000; Norton et al., 2011; Reuss et al., 2010; Saros et al., 2010). A response of chironomids to the input of phosphorous in mineral colloids from glaciers was described more than 50 years ago (Brundin, 1956, 1958). Of the ten sites presented by Velle et al. (2010a), multiproxy studies indicate that four of the chironomid-based temperature inferences, and not two as stated by Brooks et al. (2012), could be obscured by an early-Holocene increase in productivity (SPA: Hammarlund et al., 2004; L850: Larocque and Bigler, 2004; RAT: Velle et al., 2005b; BRU: Velle et al., 2010b). Furthermore, an increase in rainfall may result in enhanced in-wash of nutrients into water bodies (Chang et al., 2001; Kundzewicz et al.,
2007). If this happened in the past, the chironomid-inferred temperatures could accordingly be overestimated. A response to nutrient-input was illustrated in a study on experimental fertilization in Alaska. During the six study years, the dominating chironomid genus in the fertilised side of the lake changed from Heterotrissocladius to Phaenopsectra (Hershey, 1992). There were no corresponding changes in the test side of the lake. Phaenopsectra has higher temperature optima than Heterotrissocladius (Eggermont and Heiri, 2011), and any temperature inference at this site would accordingly be overestimated.

\section{Down-core influence of human impact, $\mathrm{pH}$, and depth}

Brooks et al. (2012) recognise that human impact can influence the temperature reconstructions, but that the influence from humans can be discerned and distinguished from climate responses in chironomid records. We agree that potential human impact can be detected at sites where background information exists on the timing and extent of human influence and from multiproxy studies, such as those cited in Brooks et al. (2012). For many sites, however, information on human impact or impact along other confounding gradients is missing. At such sites, the confounding impact would potentially be interpreted as a temperature signal. Because of biases in the inferred temperatures associated with human impact in the Alpine region, Heiri and Lotter (2005) recommended a multiproxy approach to palaeoenvironmental reconstruction. According to Heiri and Lotter (2005), it is clearly essential to keep a close control on changes in local human activity during the late Holocene, even at high elevations and in remote mountain lakes.

When it comes to the influence of lake depth and $\mathrm{pH}$, Brooks et al. (2012) agree that there is a possible problem of confounding gradients that can cause unreliable chironomid-inferred temperature estimates.

\section{Training-sets as representatives of true pattern in nature}

The complexity and multidimensionality in chironomid responses to environmental variables in modern data sets and in down-core sequences, as demonstrated above and in Velle et al. (2010a), suggest that transfer functions should not be interpreted as representatives of true ecological patterns in nature. Training-sets can help build ecological hypothesis, but should be seen as empirical models that mimic a small fraction of the biological response mechanisms. It is important to separate responses in static and optimised training-sets in space, from responses along gradual changes within single lakes in time. As an example, Axford et al. (2009) found that some taxa appeared to exhibit different temperature preferences in a core from Iceland and in the Iceland calibration data set. We concur with Huntley (2012), who cautions against using biological proxies to reconstruct variables in isolation since most organisms respond concurrently to several variables. A strong implication is that chironomids can be used as a proxy for combinations of variables that often occur together, such as tropho-dynamic status sensu Catalan et al. (2009). Tropho-dynamic status is a combination of variables, including productivity (DOC, total phosphorus), thermal conditions, and littoral habitat features.

\section{Concluding remarks}

All scientific results should be subject to rigorous testing. This is not straightforward when we use proxies to infer some unknown environmental variable of the past (Birks et al., 2010). In this context, we do not see how Brooks et al. (2012) have provided 
evidence that Holocene chironomid-based temperature reconstructions are reliable, as they state. Similarities with other proxies or multiple sites are needed to confirm results and the similarities should be tested for statistical significance. We do not believe these challenges involved are unique to chironomids as a palaeoenvironmental proxy (e.g. Huntley, 2012). This was highlighted in the title of the Velle et al. Forum Article as 'lessons for palaeoecology'. As Brooks et al. (2012) noted '...t h e requirement for multiproxy and multisite studies to separate signal from noise is equally true for other climate proxies, including lacustrine proxies and proxies from other archives such as tree rings, peats, speleothems and ice cores'. These are general challenges that we hope experts in their respective fields of palaeoenvironmental sciences will take seriously. Recognising that other sciences have challenges is no excuse not to take these challenges seriously in chironomid research. We do not wish palaeoecologists to dismiss their biological proxies, but rather to use more resources to understand the underlying ecological processes and to refine their palaeoecological methods. Then, the resulting palaeoenvironmental inferences will hopefully be more robust.

\section{Acknowledgements}

We would like to thank Stephen Brooks, Yarrow Axford, Oliver Heiri, Peter Langdon, and Isabelle Larocque-Tobler for contributing to this debate. We also acknowledge Richard Telford, Godtfred Anker Halvorsen, and Ladislav Hamerlik for valuable discussions. Richard Telford helped produce Figure 2.

\section{Funding}

This work has been supported by the Norwegian Research Council through grant $178653 / \mathrm{S} 30$ to $\mathrm{GV}$.

\section{References}

Antonsson K, Brooks SJ, Seppa H et al. (2006) Quantitative palaeotemperature records inferred from fossil pollen and chironomid assemblages from Lake Gilltjarnen, northern central Sweden. Journal of Quaternary Science 21: 831-841.

Axford Y, Geirsdóttir Á, Miller G et al. (2009) Climate of the Little Ice Age and the past 2000 years in northeast Iceland inferred from chironomids and other lake sediment proxies. Journal of Paleolimnology 41: 7-24.

Barley EM, Walker IR, Kurek J et al. (2006) A northwest North American training set: Distribution of freshwater midges in relation to air temperature and lake depth. Journal of Paleolimnology 36: 295-314.

Bennett KD (2002) Comment: the Greenland 8200 cal.yr BP event detected in loss-on-ignition profiles in Norwegian lacustrine sequences - Correspondence. Journal of Quaternary Science 17: 97-99.

Bigler C, Larocque I, Peglar SM et al. (2002) Quantitative multiproxy assessment of long-term patterns of Holocene environmental change from a small lake near Abisko, northern Sweden. The Holocene 12: 481-496.

Bigler C, Grahn E, Larocque I et al. (2003) Holocene environmental change at Lake Njulla (999 m a.s.1.), northern Sweden: A comparison with four small nearby lakes along an altitudinal gradient. Journal of Paleolimnology 29: 13-29.

Bigler C, Heiri O, Krskova R et al. (2006) Distribution of diatoms, chironomids and cladocera in surface sediments of thirty mountain lakes in southeastern Switzerland. Aquatic Sciences 68: 154-171.

Birks HJB (1998) Numerical tools in palaeolimnology - Progress, potentialities, and problems. Journal of Paleolimnology 20: 307-332.

Birks HJB, Heiri O, Seppä H et al. (2010) Strengths and weaknesses of quantitative climate reconstructions based on Late-Quaternary biological proxies. The Open Ecology Journal 3: 68-110.

Boyle JF (2007) Loss of apatite caused irreversible early-Holocene lake acidification. The Holocene 17: 543-547.

Brazdil R, Dobrovolny P, Luterbacher J et al. (2010) European climate of the past 500 years: New challenges for historical climatology. Climatic Change 101: 7-40.

Brodersen KP and Anderson NJ (2002) Distribution of chironomids (Diptera) in low arctic West Greenland lakes: Trophic conditions, temperature and environmental reconstruction. Freshwater Biology 47: 1137-1157.
Brodersen KP and Lindegaard C (1999) Classification, assessment and trophic reconstruction of Danish lakes using chironomids. Freshwater Biology 42: $143-157$

Brooks S, Heiri O, Axford Y et al. (2012) Chironomids can be reliable proxies for Holocene temperatures. A comment on Velle et al. (2010). The Holocene $\mathrm{XX}$ : $\mathrm{XX}-\mathrm{XX}$ (this issue).

Brooks SJ (2006) Fossil midges (Diptera: Chironomidae) as palaeoclimatic indicators for the Eurasian region. Quaternary Science Reviews 25: 1894-1910.

Brooks SJ and Birks HJB (2001) Chironomid-inferred air temperatures from Late-glacial and Holocene sites in north-west Europe: Progress and problems. Quaternary Science Reviews 20: 1723-1741.

Brooks SJ, Bennion H and Birks HJB (2001) Tracing lake trophic history with a chironomid-total phosphorus inference model. Freshwater Biology 46: 513-533.

Brundin L (1949) Chironomiden und andere Bodentiere der Südschwedischen Urgebirgsseen. Report of the Institute of Freshwater Research Drottningholm 30: 1-194.

Brundin L (1956) Die bodenfaunistichen Seetypen und ihre Anwendbarkeit auf die Südhalbkugel. Report of the Institute of Freshwater Research Drottningholm 37: 186-235.

Brundin L (1958) The bottom faunistical lake type system and its application to the southern hemisphere. Moreover a theory of glacial erosion as a factor of productivity in lakes and oceans. Verhandlungen der internationalen Vereingung theoretische und angewandte Limnologie 13: 288-297.

Burman P, Chow E and Nolan D (1994) A cross-validatory method for dependent data. Biometrika 81: 351-358

Cameron NG, Schnell OA, Rautio ML et al. (2002) High-resolution analyses of recent sediments from a Norwegian mountain lake and comparison with instrumental records of climate. Journal of Paleolimnology 28: 79-93.

Casty C, Raible CC, Stocker TF et al. (2007) A European pattern climatology 1766-2000. Climate Dynamics 29: 791-805.

Casty C, Wanner H, Luterbacher J et al. (2005) Temperature and precipitation variability in the european Alps since 1500. International Journal of Climatology 25: 1855-1880.

Catalan J, Barbieri MG, Bartumeus F et al. (2009) Ecological thresholds in European alpine lakes. Freshwater Biology 54: 2494-2517.

Chang HJ, Evans BM and Easterling DR (2001) The effects of climate change on stream flow and nutrient loading. Journal of the American Water Resources Association 37: 973-985.

Dalton C, Birks HJB, Brooks SJ et al. (2005) A multi-proxy study of lakedevelopment in response to catchment changes during the Holocene at Lochnagar, north-east Scotland. Palaeogeography Palaeoclimatology Palaeoecology 221: 175-201.

Dobrovolny P, Moberg A, Brazdil R et al. (2010) Monthly, seasonal and annual temperature reconstructions for Central Europe derived from documentary evidence and instrumental records since AD 1500. Climatic Change 101: 69-107.

Eggermont $\mathrm{H}$ and Heiri O (2011) The chironomid-temperature relationship: Expression in nature and palaeoenvironmental implications. Biological Reviews of the Cambridge Philosophical Society: DOI 10.1111/j.14691185X.2011.00206.x.

Engstrom DR and Fritz SC (2006) Coupling between primary terrestrial succession and the trophic development of lakes at Glacier Bay, Alaska. Journal of Paleolimnology 35: 873-880.

Engstrom DR, Fritz SC, Almendinger JE et al. (2000) Chemical and biological trends during lake evolution in recently deglaciated terrain. Nature 408: 161-166.

Fjellheim A, Raddum GG, Vandvik V et al. (2009) Diversity and distribution patterns of benthic invertebrates along alpine gradients. A study of remote European freshwater lakes. Advances in Limnology 62: 167-190.

Hammarlund D, Velle G, Wolfe BB et al. (2004) Palaeolimnological and sedimentary responses to Holocene forest retreat in the Scandes Mountains, west-central Sweden. The Holocene 14: 862-876.

Heider VC (2004) Late Pleistocene and Holocene paleolimnology and climate history in southern Sweden reconstructed from chironomid, diatoms and pollen records. Doctor of Natural Sciences Thesis. Braunschweig: der Technischen Universität Carolo-Wilhelmina zu Braunschweig.

Heinrichs ML, Peglar SM, Bigler C et al. (2005) A multi-proxy palaeoecological study of Alanen Laanijärvi, a boreal-forest lake in Swedish Lapland. Boreas 34: 192-206.

Heiri C, Bugmann H, Tinner W et al. (2006) A model-based reconstruction of Holocene treeline dynamics in the Central Swiss Alps. Journal of Ecology 94: 206-216.

Heiri O and Lotter AF (2003) 9000 years of chironomid assemblage dynamics in an Alpine lake: Long-term trends, sensitivity to disturbance, and resilience of the fauna. Journal of Paleolimnology 30: 273-289. 
Heiri O and Lotter AF (2005) Holocene and Lateglacial summer temperature reconstruction in the Swiss Alps based on fossil assemblages of aquatic organisms: A review. Boreas 34: 506-516.

Heiri O, Brooks SJ, Birks HJB et al. (2011) A 274-lake calibration data-set and inference model for chironomid-based summer air temperature reconstruction in Europe. Quaternary Science Reviews 30: 3445-3456.

Heiri O, Lotter AF, Hausmann S et al. (2003) A chironomid-based Holocene summer air temperature reconstruction from the Swiss Alps. The Holocene 13: 477-484.

Hershey AE (1992) Effects of experimental fertilization on the benthic macroinvertebrate community of an Arctic lake. Journal of the North American Benthological Society 11: 204-217.

Huntley B (2012) Reconstructing palaeoclimates from biological proxies: Some often overlooked sources of uncertainty. Quaternary Science Reviews 31: 1-16.

Jones PD and Moberg A (2003) Hemispheric and large-scale surface air temperature variations: An extensive revision and an update to 2001. Journal of Climate 16: 206-223.

Kernan M, Ventura M, Bitušík P et al. (2009) Regionalisation of remote European mountain lake ecosystems according to their biota: Environmental versus geographical patterns. Freshwater Biology 54: 2470-2493.

Korhola A, Olander H and Blom T (2000) Cladoceran and chironomid assemblages as quantitative indicators of water depth in subarctic Fennoscandian lakes. Journal of Paleolimnology 24: 43-54.

Korhola A, Vasko K, Toivonen HTT et al. (2002) Holocene temperature changes in northern Fennoscandia reconstructed from chironomids using Bayesian modelling. Quaternary Science Reviews 21: 1841-1860.

Kundzewicz ZW, Mata LJ, Arnell NW et al. (2007) Freshwater resources and their management. In: Parry ML, Canziani OF, Palutikof JP et al. (eds) Climate Change 2007: Impacts, Adaptation and Vulnerability. Contribution of Working Group II to the Fourth Assessment Report of the Intergovernmental Panel on Climate Change. Cambridge: Cambridge University Press, pp. 173-210.

Langdon PG, Holmes N and Caseldine CJ (2008) Environmental controls on modern chironomid faunas from NW Iceland and implications for reconstructing climate change. Journal of Paleolimnology 40: 273-293.

Larocque I and Bigler C (2004) Similarities and discrepancies between chironomid- and diatom-inferred temperature reconstructions through the Holocene at Lake 850, northern Sweden. Quaternary International 122: $109-121$.

Larocque I and Hall RI (2003) Chironomids as quantitative indicators of mean July air temperature: Validation by comparison with century-long meteorological records from northern Sweden. Journal of Paleolimnology 29: 475-493.

Larocque I, Grosjean M, Heiri O et al. (2009) Comparison between chironomid-inferred July temperatures and meterological data AD 1850 - 2001 from varved Lake Silvaplana, Switzerland. Journal of Paleolimnology 41: 329-342.

Larocque I, Hall RI and Grahn E (2001) Chironomids as indicators of climate change: A 100-lake training set from a subarctic region of northern Sweden (Lapland). Journal of Paleolimnology 26: 307-322.

Larocque I, Pienitz R and Rolland N (2006) Factors influencing the distribution of chironomids in lakes distributed along a latitudinal gradient in northwestern Quebec, Canada. Canadian Journal of Fisheries and Aquatic Sciences 63: 1286-1297.

Lenz F (1925) Chironomiden and Seetypenlehre. Die Naturwissenschaften 13 $5-10$

Lotter AF, Appleby PG, Bindler R et al. (2002) The sediment record of the past 200 years in a Swiss high-alpine lake: Hagelseewli (2339 m a.s.1.). Journal of Paleolimnology 28: 111-127.

Lotter AF, Birks HJB, Hofmann W et al. (1997) Modern diatom, cladocera, chironomid, and chrysophyte cyst assemblages as quantitative indicators for the reconstruction of past environmental conditions in the Alps .1. Climate. Journal of Paleolimnology 18: 395-420.

Lotter AF, Birks HJB, Hofmann W et al. (1998) Modern diatom, cladocera, chironomid, and chrysophyte cyst assemblages as quantitative indicators for the reconstruction of past environmental conditions in the Alps. II. Nutrients. Journal of Paleolimnology 19: 443-463.

Lüder B (2007) The potential of non-alpine lakes for quantitative palaeotemperature reconstructions based on subfossil chironomids: A comparative palaeolimnological study from southern Norway. Doctor of Natural Sciences (thesis). Bremen: Universität Bremen.

Luoto TP (2010) Hydrological change in lakes inferred from midge assemblages through use of an intralake calibration set. Ecological Monographs 80: 303-329.

Luoto TP and Salonen VP (2010) Fossil midge larvae (Diptera: Chironomidae) as quantitative indicators of late-winter hypolimnetic oxygen in southern
Finland: A calibration model, case studies and potentialities. Boreal Environment Research 15: 1-18.

Luoto TP, Kultti S, Nevalainen L et al. (2010) Temperature and effective moisture variability in southern Finland during the Holocene quantified with midge-based calibration models. Journal of Quaternary Science 25: 1317-1326.

Luterbacher J, Dietrich D, Xoplaki E et al. (2004) European seasonal and annual temperature variability, trends, and extremes since 1500. Science 303: 1499-1503.

Meier N, Rutishauser T, Pfister C et al. (2007) Grape harvest dates as a proxy for Swiss April to August temperature reconstructions back to AD 1480. Geophysical Research Letters 34: L20705, doi:10.1029/2007GL031381.

Moberg A, Tuomenvarta H and Nordli Ø (2005) Recent climatic trends. In: Seppälä M (ed.) The Physical Geography of Fennoscandia. Oxford: Oxford University Press, pp. 113-134.

Nordli PO, Lie O, Nesje A et al. (2003) Spring-summer temperature reconstruction in western Norway 1734-2003: A data-synthesis approach. International Journal of Climatology 23: 1821-1841.

Norton SA, Perry RH, Saros JE et al. (2011) The controls on phosphorus availability in a Boreal lake ecosystem since deglaciation. Journal of Paleolimnology 46: 107-122.

Nyman M, Korhola A and Brooks SJ (2005) The distribution and diversity of Chironomidae (Insecta: Diptera) in western Finnish Lapland, with special emphasis on shallow lakes. Global Ecology and Biogeography 14: 137-153.

Nyman M, Weckström J and Korhola A (2008) Chironomid response to environmental drivers during the Holocene in a shallow treeline lake in northwestern Fennoscandia. The Holocene 18: 215-227.

Olander H, Birks HJB, Korhola A et al. (1999) An expanded calibration model for inferring lakewater and air temperatures from fossil chironomid assemblages in northern Fennoscandia. The Holocene 9: 279-294.

Paus A, Velle G and Berge J (2011) The Lateglacial and early Holocene vegetation and environment in the Dovre mountains, central Norway, as signalled in two Lateglacial nunatak lakes. Quaternary Science Reviews 30: 1780-1796.

Porinchu D, Rolland N and Moser K (2009) Development of a chironomidbased air temperature inference model for the central Canadian Arctic. Journal of Paleolimnology 41: 349-368.

Porinchu DF, MacDonald GM, Bloom AM et al. (2002) The modern distribution of chironomid sub-fossils (Insecta: Diptera) in the Sierra Nevada, California: Potential for paleoclimatic reconstructions. Journal of Paleolimnology 28: 355-375.

Quinlan R and Smol JP (2001) Chironomid-based inference models for estimating end-of-summer hypolimnetic oxygen from south-central Ontario shield lakes. Freshwater Biology 46: 1529-1551.

Real M and Prat N (1992) Factors influencing the distribution of chironomids and oligochaetes in profundal areas of Spanish reservoirs. Aquatic Ecology 26: 405-410.

Rees ABH and Cwynar LC (2010) A test of Tyler's Line - Response of chironomids to a $\mathrm{pH}$ gradient in Tasmania and their potential as a proxy to infer past changes in pH. Freshwater Biology 55: 2521-2540.

Rees ABH, Cwynar LC and Cranston PS (2008) Midges (Chironomidae, Ceratopogonidae, Chaoboridae) as a temperature proxy: A training set from Tasmania, Australia. Journal of Paleolimnology 40: 1159-1178.

Reuss NS, Hammarlund D, Rundgren M et al. (2010) Lake ecosystem responses to Holocene climate change at the subarctic tree-line in northern Sweden. Ecosystems 13: 393-409.

Rosén P, Segerstrom U, Eriksson L et al. (2001) Holocene climatic change reconstructed from diatoms, chironomids, pollen and near-infrared spectroscopy at an alpine lake (Sjuodjljaure) in northern Sweden. The Holocene 11: 551-562.

Sæther OA (1979) Chironomid communities as water quality indicators. Holarctic Ecology 2: 65-74.

Saros JE, Rose KC, Clow DW et al. (2010) Melting alpine glaciers enrich highelevation lakes with reactive nitrogen. Environmental Science \& Technology 44: 4891-4896.

Self AE, Brooks SJ, Birks HJB et al. (2011) The distribution and abundance of chironomids in high-latitude Eurasian lakes with respect to temperature and continentality: Development and application of new chironomidbased climate-inference models in northern Russia. Quaternary Science Reviews 30: 1122-1141.

Seppä H, Nyman M, Korhola A et al. (2002) Changes of treelines and alpine vegetation in relation to post-glacial climate dynamics in northern Fennoscandia based on pollen and chironomid records. Journal of Quaternary Science 17: 287-301.

Telford R and Birks HJB (2011) A novel method for assessing the significance of quantitative reconstructions inferred from biotic assemblages Quaternary Science Reviews 30: 1272-1278. 
Thienemann A (1928) Der Sauerstoff im eutrophen und oligotrophen See: ein Beitrag zur Seetypenlehre. Stuttgart.

Thienemann A (1954) Chironomus. Leben, Verbreitung und wirtschaftliche Bedeutung der Chironomiden. Binnengewässer 20: 1-834.

Tian J, Nelson D and Hu F (2011) How well do sediment indicators record past climate? An evaluation using annually laminated sediments. Journal of Paleolimnology 45: 73-84.

Velle G, Bjune AE, Larsen J et al. (2010b) Holocene climate and environmental history of Brurskardstjørni, a lake in the catchment of Øvre Heimdalsvatn, south-central Norway. Hydrobiologia 642: 13-34.

Velle G, Brodersen KP, Birks HJB et al. (2010a) Midges as quantitative temperature indicator species: Lessons for palaeoecology. The Holocene 20: 989-1002.

Velle G, Brooks SJ, Birks HJB et al. (2005a) Chironomids as a tool for inferring Holocene climate: An assessment based on six sites in southern Scandinavia. Quaternary Science Reviews 24: 1429-1462.
Velle G, Kongshavn K and Birks HJB (2011) Minimizing the edge-effect in environmental reconstructions by trimming the calibration set: Chironomid-inferred temperatures from Spitsbergen. The Holocene 21: 417-430.

Velle G, Larsen J, Eide W et al. (2005b) Holocene environmental history and climate of Ratasjoen, a low-alpine lake in south-central Norway. Journal of Paleolimnology 33: 129-153.

Walker IR, Smol JP, Engstrom DR et al. (1991) An assessment of Chironomidae as quantitative indicators of past climatic change. Canadian Journal of Fisheries and Aquatic Sciences 48: 975-987.

Wiederholm TE and Erikson L (1979) Subfossil chironomids as evidence of eutrophication in Ekoln Bay, Central Sweden. Hydrobiologia 62: 195-208.

Zhang E, Jones R, Bedford A et al. (2007) A chironomid-based salinity inference model from lakes on the Tibetan Plateau. Journal of Paleolimnology 38: $477-491$. 